Volume 1, Number 1, October 2021

\title{
The Role, Development and Opportunities of Spice Commodities for International Relations between Indonesia and Other Countries in the International Market
}

\author{
Wahyu Adhi Saputro ${ }^{1}$, Herdiana Anggrasari ${ }^{2}$ \\ ${ }^{1}$ Agribusiness Study Program, Universitas Duta Bangsa Surakarta, Indonesia \\ ${ }^{2}$ Agribusiness Study Program, Universitas Tribhuwana Tunggadewi, Indonesia \\ Correspondence: Wahyu Adhi Saputro, Universitas Duta Bangsa Surakarta, Indonesia. \\ E-mail:wahyuadhi@udb.ac.id \\ Received: April 1, 2021 Accepted: September 12, 2021 Online Published: October 28, 2021
}

\begin{abstract}
Indonesia as a spice producer has the opportunity to become a world spice exporter that can contribute to the Indonesian economy. On the other hand, Indonesia has challenges to be able to improve the performance of Indonesian spices commodities. In this research, an overview of the condition of Indonesian spices will be seen so that the development and opportunities of Indonesian spices can be identified. Therefore the objectives of this study are (1) to determine the development of the area, production and productivity of Indonesian spices, (2) to determine the development and performance of international trade in Indonesian spices, (3) the demand for world and Indonesian spices. in the international market, and (4) the development of world and Indonesian spices prices in the international market. This research uses the basic analytical descriptive method, which is a research method that focuses on solving actual problems in the present. The results showed that in general the acreage and production of spices commodities tended to increase from year to year, but the productivity of pepper, nutmeg and vanilla decreased. When viewed from the balance of the Indonesian spices trade in each period it fluctuates but tends to increase. Meanwhile, the demand for spices in the international and Indonesian markets fluctuates every year but tends to increase and the development of international and domestic spice commodity prices has fluctuated each period.
\end{abstract}

Keywords: Indonesia, Spices, Commodities, Ekspor, Trade

\section{Introduction}

The Indonesian spices commodity is one of the commodities in the plantation sub-sector that has great opportunities in the international market. Indonesia as a spice producer has the opportunity to become a world spice exporter that can contribute to the Indonesian economy. Spices include several groups of commodities that play an important role in supporting human food needs. It is estimated that there are 400-500 spices in the world. Where Southeast Asia is the center of the world spice region. In Southeast Asia there are approximately 275 species of spices with important spices, namely Javanese cardamom, cinnamon, cloves, ginger, nutmeg, black pepper and others (Hakim, L. 2015). According to Yuliati (Yuliati, L. 2012), in the 12th century Southeast Asian spices were very popular in Europe and became a cure for all kinds of diseases. Apart from that, spices are also used as seasonings and preservatives in food.

According to Hermawan (Hermawan, Iwan. 2015), the spice trade in the international market continues to grow rapidly. Some of the reasons for the increased demand for spices in the international market can be because Asian and developed countries are experiencing economic growth which causes increased consumption of ready-to-eat food, increased public awareness of the benefits of spices for health ( FAO. 2014), the 
development of the culinary industry for attracting domestic and foreign tourists, for example rendang (Indonesia), nasi lemak (Malaysia), laksa (Singapore), tom yum (Thailand), and adobo (Philippines), as well as cultural changes in socializing, namely eating and gathering in restaurants to become part of important for building social relationships ( Sutriyanto, E. 2014).

Since the 1960s, the quantity of the global spice trade has increased exponentially, the value of the international trade in spices (in nominal terms) has increased by 41 -fold which represents a slightly higher rate of increase in the overall food trade (Lakner, Zoltán, Erzsébet Szabó, Viktória Szücs, and A. S. 2018). The demand for natural ingredients including spices in the world in the future will increase in line with population growth, economy, health demands and increasingly expensive synthetic products, and increasing awareness of environmental sustainability ( Ferry, Y. 2013). The trend of world spice commodity demand has a tendency to increase every year with a demand rate of $10.38 \%$ per year. This shows that the spice commodity has a prospective market and plays an important role in the international market.

The increase in world demand for spice commodities is in line with the increase in exports of Indonesian spice commodities in the international market. The average growth rate of Indonesian exports increased by $8.07 \%$ per year but the average contribution value of Indonesian spices in the international market tended to decrease every year from 1989 to 2017. In the 1989-1997 period, the share of Indonesian spices exports reached 14.78\%, but then experienced a a decrease in the share of spices exports to $7.83 \%$ in the $2008-2017$ period. This shows that Indonesia has not been able to keep up with the trend of increasing world demand for spices.

The performance of Indonesia's spice trade needs to be improved again to take advantage of export opportunities in the international market which are still wide open. Indonesia has a great opportunity to expand its market share. However, on the other hand, Indonesia has challenges to be able to improve the performance of Indonesia's spices commodity because the contribution of exports is still low compared to commodities in other agricultural sectors. In 2016, Indonesia's spice commodities only contributed $2.7 \%$ of the total exports of the agricultural sector. Meanwhile, in 1997 the spice commodity contributed up to $3.88 \%$. This shows that the performance of Indonesia's spice commodities has decreased.

Cooperation between countries could be a solution to the development of existing industries. However, Indonesia must continue to strengthen its resources so that many countries are willing to establish cooperation in various sectors ( Manurung, H. (2021). It should also be considered if between countries want export and import needs, especially in terms of economic distance including transportation costs charged to importers, delivery times and communication costs. It also needs to be seen whether there are obstacles such as import duty rates, taxes on goods, duties and others ( Kis-Katos, K., \& Sparrow, R. 2015). than the international country of things that to give the profit to the state of the country of the things of the relative and our products of the things which are which to work of import is the activities that very essential ( Benesova, I., Maitah, M., Smutka, L., Tomsik, K., \& Ishchukova, N. 2017), (Beaudreau, B. C. 2011). The tendency of a country to trade because of the country's specialization in a product so that it has strong competitiveness. ( Laursen, K. 2015).

Various efforts need to be made by Indonesia to expand market share, improve trade performance, and increase the quality and productivity of Indonesian spices. In research conducted by Chasanah et. al (Chasanah, N., Mulyo, J. H., \& Darwanto, D. H. 2017). States that one of the spice commodities, biopharmaca, still has a high potential to be developed because competition for these commodities is still low. In addition, the spice commodity still has relatively specific characte(ristics in its endowment factor ownership because it is only found in a few countries. Therefore the objectives of this study are (1) to determine the development of the area, production and productivity of Indonesian spices, (2) to determine the development and performance of international trade in Indonesian spices, (3) the demand for world and Indonesian spices. in the international market, and (4) the development of world and Indonesian spices prices in the international market.

\section{Method}

This research uses the basic analytical descriptive method, which is a research method that focuses on solving actual problems in the present. Data collection was carried out and then analyzed and explained. Descriptive research aims to be able to provide a systematic description of a fact and the characteristics of an object or 
subject accurately. The data used in this study is secondary data, namely data obtained based on the results of literature studies of various archives and statistical data from related agencies. Secondary data in this study include data on area area, production, productivity from FAO (fao.org) and data on exports and imports from UN Comtrade (comtrade.un.org). The limited researched spices commodity based on the Harmonized Commodity Description and Coding System (HS) code sourced from UNComtrade (2019) includes codes 0904 (pepper, chili, capsicum), 0905 (vanilla), 0906 (cinnamon), 0907 (cloves ), 0908 (nutmeg, lawang, cardamom), and 0910 (biopharmaca) for spices with data spanning from 1989 to 2017.

\section{Results}

\subsection{The Role of Indonesian Spices Commodities in Improving International Relationships}

Development of Area, Production, Productivity of Indonesian Spices

FAO data shows that in 2017 the area of spices in Indonesia was 3.41\% of the total area of agricultural land in Indonesia, which is around 30.52 million ha. The development of the area of spices in Indonesia from 2000 to 2017 can be seen in Figure 4. For 18 years (2000-2017) there has been an increase in the area of Indonesian spices with a growth rate of $81.98 \%$ in pepper; $92.44 \%$ for vanilla; $59.89 \%$ for cinnamon; $40.53 \%$ in cloves; $350.51 \%$ for nutmeg; and $38.64 \%$ in one of the biopharmaceutical commodities, namely ginger. Based on data obtained from FAO, the area of the spice commodity in 2017 based on the highest ranking, namely cloves, pepper, nutmeg, cinnamon, vanilla, and ginger with an area of 548,091 ha, 181,978 ha, 180,250 ha, 105,503 ha, 15,203 ha and 10,556 ha.

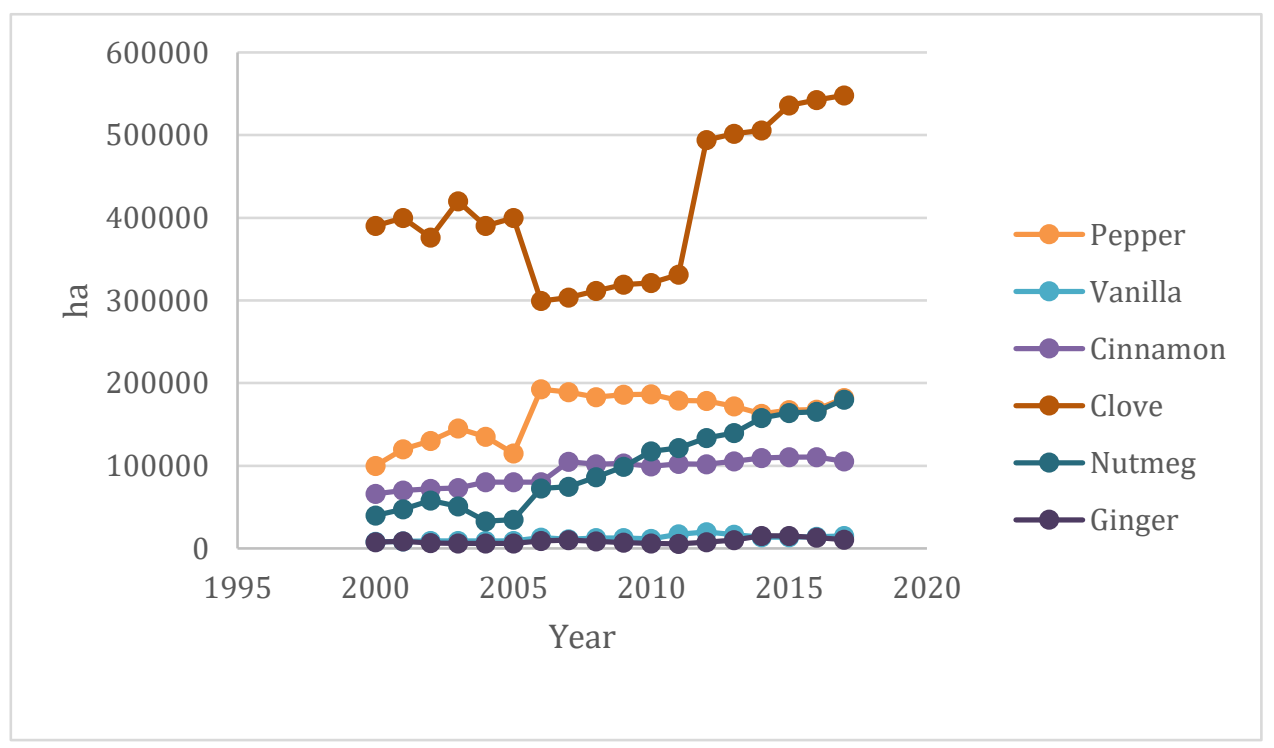

Figure 1. Development of Indonesian Spice Commodities 2000-2017 Source: Secondary data analysis (FAO, 2018)

For 18 years, nutmeg had the largest acreage growth rate with a positive growth rate. The area of nutmeg shows an increase every year with an average of $11.98 \%$. However, in 2003 and 2004 the area of nutmeg decreased by 7,235 ha and 17,860 ha. Then starting from 2005 to 2017 there was a continuous increase in the area of the nutmeg commodity. Apart from nutmeg, the development of vanilla area has also increased. During the 18 years, the rate of increase in the area of vanilla area was $5.28 \%$ per year. The area of vanilla area also fluctuates although it has a trend that tends to increase. According to Rosman (Rosman, R. 2005), an increase in the area of vanilla shows the attractiveness of this commodity because of its high economic value. The development of the vanilla planting area cannot be separated from the support of existing technology. In 1983 the area for vanilla development was mostly in Lampung and Java Island. However, the development of information technology as well as the number of meetings and seminars held by various agencies led to vanilla cultivation starting to spread to almost all provinces in Indonesia, one of which is in Sumbawa, West Nusa Tenggara.

The pepper commodity has an area increase rate of $4.75 \%$ per year. $99.87 \%$ of the pepper area is controlled by 
smallholder plantations. Therefore, the decrease in the area of pepper is very much determined by the decrease or increase in the area of smallholder plantations. The area of pepper tends to fluctuate. In 2004 and 2005 there was a decrease in the area of pepper by $7 \%$ and $14 \%$. Pusdatin (2015) explains that after 2003, the national pepper area decreased due to the conversion of pepper plants to other plantation commodities. In addition, what caused a decrease in the area of pepper was the cultivation carried out by traditional smallholder plantations so that the production obtained was not optimal and limited capital made farmers shift their business to other plantation commodities which were considered more profitable than pepper. Meanwhile, cinnamon has an area increase rate of $3.05 \%$ per year for 18 years. Cinnamon acreage fluctuates and has an increasing trend. The area of ginger area also experienced an increasing trend, the area of ginger in 2000, which was 7,614 ha, grew to 10,556 ha in 2017. Even so, the area of ginger has fluctuated every year, the rate of increase in the area of ginger is positive each year, namely $4.33 \%$ per year.

Based on Figure 1, it can be seen that the largest landholding area in the commodity of spices is cloves with a growth rate of clove area of $40.53 \%$ for 18 years (2000-2017) and a rate of increase in area per year of $2.85 \%$. The development of clove area has a positive trend, although in 2004 and 2006 there was a decrease in the area of cloves. Pusdatin (2014) explains that in the period after the economic crisis in 1998, the development of the kretek cigarette industry began to increase with the increasing need for cloves and starting to improve the selling price of cloves. This has led farmers in some areas to become interested in replanting damaged or dead clove plants. Therefore, in 2001, the expansion of the area of cloves began to appear, even though the growth was still very slow. During the period 1998 - 2013 the total area of cloves increased by $0.48 \%$ per year.

The decrease in acreage can be caused by land conversion or conversion to other commodities. Many spices are cultivated by smallholder plantations which result in cultivated plants susceptible to pests and diseases so that production is not optimal. With limited capital, farmers prefer to shift their business to other plantation commodities that are considered more profitable (Pusdatin, 2016; Pusdatin, 2015).

For fifteen years, the most consistent trend of increasing area was for cinnamon, cloves, and the commodity groups of nutmeg, mace and cardamom. The increase in area indicated that the spice commodity was still economically profitable. The increase in acreage of these commodities is also in line with the increase in production (figure 2).

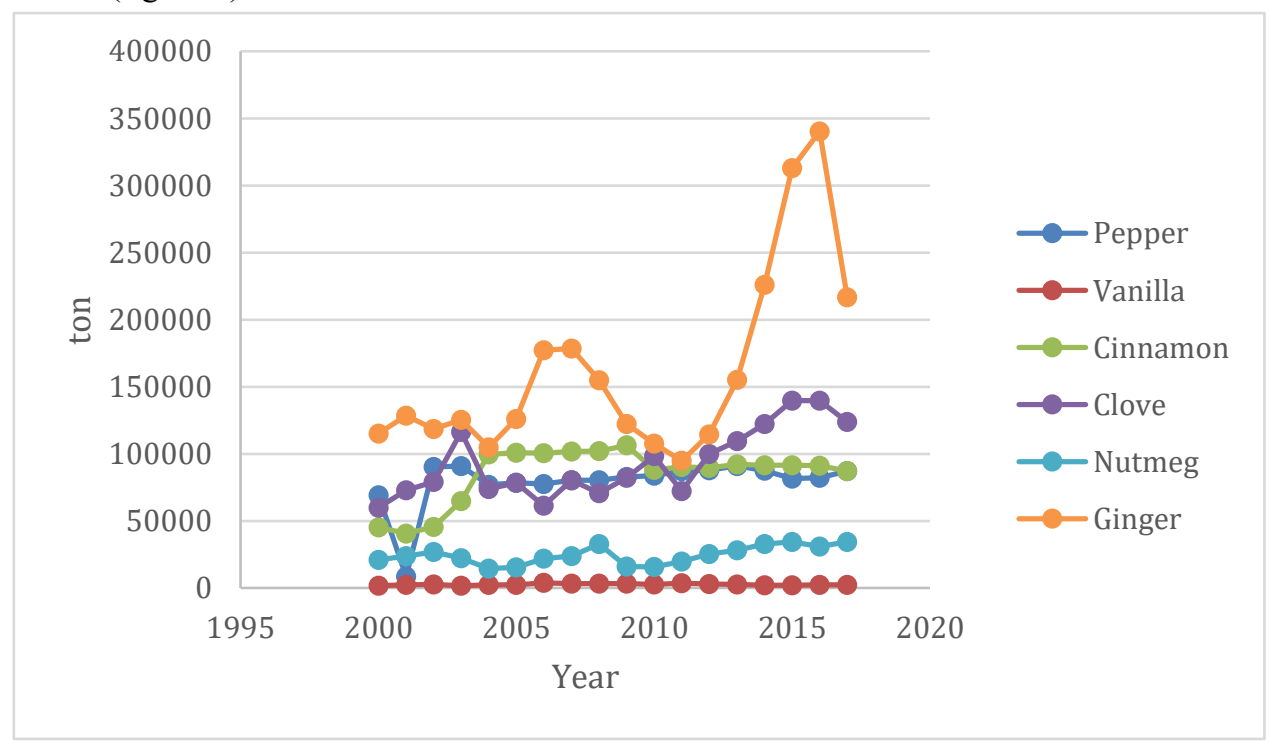

Figure 2. Development of Indonesian Spice Commodities Production, 2000-2017 Source: Secondary data analysis (FAO, 2018)

During the period 2000-2017, spice production experienced different developments in each commodity group. However, overall the trend of production tends to increase with the largest growth rate, namely cloves $106.705 \%$ with an increase in production of 63,894 tons, cinnamon $92.61 \%$ with an increase in production of 41,893 tons, ginger $88.18 \%$ with an increase in production of 101,495 tons, nutmeg $63,49 \%$ with an increase in production 
of 13,354 tons, vanilla $42.89 \%$ with an increase in production of 721 tons, and pepper $25.97 \%$ with an increase in production of 17,942 tons over a period of 18 years (2000-2017). The development of ginger commodity production is very good every year even though the control of ginger commodity land area is the smallest. This shows that ginger has good productivity. In figure 6, you can see the development of Indonesia's spice commodity productivity in $2000-2017$.

From 2000 to 2017, ginger productivity has an increasing trend. The average rate of increasing productivity of ginger for 18 years (2000-2017) reached $35.73 \%$. In 2000 the productivity of ginger from 15.11 tonnes / ha increased to 20.52 tonnes / ha in 2017. Other commodities that also had a good increase in productivity were cinnamon and cloves with growth rates of $20.46 \%$ and $47.08 \%$. Meanwhile, the commodity of pepper, nutmeg and vanilla had a decreased productivity rate of $30.78 \% ; 63.71 \%$ and $25.75 \%$. If the decline in productivity continues while land expansion is difficult to do, it can reduce the level of production so that the export volume of these commodities can decrease.

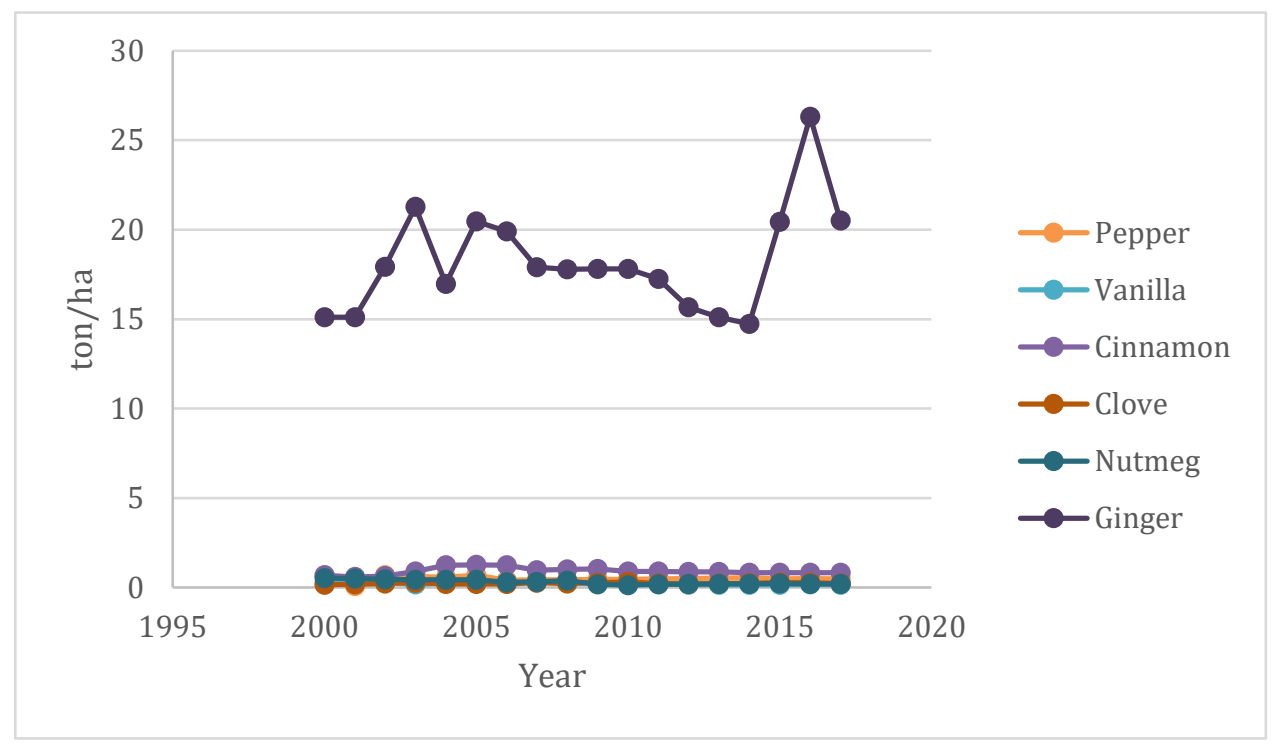

Figure 3. Development of Productivity of Indonesian Spice Commodities 2000-2017 Source: Secondary data analysis (FAO, 2018)

Based on FAO data (2018), pepper productivity decreased by 0.2 tonnes / ha for 18 years (2000-2017). In 2000 the productivity of pepper was 0.69 tonnes / ha, then in 2017 it became 0.47 tonnes / ha. The productivity of vanilla and nutmeg also decreased. In 2000 vanilla had a productivity of 0.21 tonnes / ha, then in 2017 it decreased to 0.15 / ha, while nutmeg had a productivity of 0.53 tonnes / ha in 2000 to 0.19 tonnes / ha in 2017 The productivity of spices can still be improved again because FAO data shows that during the period 1987 to 2017 the commodity of spices had reached a good level of productivity. Cinnamon has reached a productivity level of 1.25 tonnes / ha in 2005 followed by cloves of 0.31 tonnes / ha in 2010, nutmeg group 5.79 tonnes / ha in 1993, pepper 0.92 tonnes / ha in 1987 , and vanilla 0.49 tonnes / ha in 1988. Meanwhile, the highest productivity of ginger was in 2016 amounting to 26.32 tonnes / ha. Therefore, the current spice commodity has the potential to increase its productivity as in the previous year.

This causes various fluctuations in productivity. The Directorate General of Plantation (2013) states that pepper, which is one of the leading spice commodities, still has many shortcomings. One of the things that can reduce the level of productivity is the reduction of the harvested area for pepper caused by drought, pests and diseases, especially stem rot and jaundice, and conversion of land areas to mining or other plantation areas, such as oil palm, rubber or cocoa. According to research by Dhalimi ( DHALIMI, A. 2020), the low productivity and quality of cinnamon is due to the lack of quality seeds in cinnamon nurseries. The better the quality of the seeds used, the better the productivity and quality of the seeds produced. In addition, farmers' cultivation is still very 
traditional in nature so that the problems cannot be separated from the constraints of plant materials, cultivation technology, pest and disease disturbances, post-harvest, agroecology, and socio-economics which are still not profitable for cinnamon farmers. The decrease in productivity of vanilla plants can be caused by the presence of pests and diseases, one of which is vanilla stem rot, so that varieties that are resistant to pests and diseases are needed. Good cultivation methods and the use of quality seeds greatly determine the production and productivity of spices. In addition, the existence of climate change in terms of increasing temperature and light intensity can reduce the yield of some spices such as ginger (Indonesia Trade Promotion Center, 2013).

Things that can reduce the productivity of spice commodities in Indonesia are the uncertainty of prices, fluctuations in crop yields, low mastery of cultivation technology, and pests and diseases. For example, what happened to the clove commodity. The low price of cloves has caused many cloves in the garden to be dismantled and replaced with other crops. Some farmers do not dismantle clove plants from the garden, but they do not continue maintenance so that the clove trees are damaged and unproductive.

\subsection{Development and Performance of International Trade in Indonesian Spices}

There are about 40 to 50 types of spices that are traded to meet the demands of the world culinary industry (FAO, 2005). International trade in the main spices commodity has a long-term stable market, but several spices have fluctuating and unstable prices. The import value of spices in the world is estimated at US \$509 million in 1989 , then to US $\$ 9.8$ billion in 2017 . This shows that the spice commodity has good market opportunities for Indonesia.

\subsection{Development of Export-Import of Indonesian Spice Commodities}

The development of the export value of Indonesian spices from 1989-2017 has fluctuated with an increasing trend in exports. The highest export value occurred in 2015 , reaching US $\$ 871,811,165$. The increase in the value of Indonesia's exports was due to the increasing volume of exports and the price of Indonesian spices. Meanwhile, from the import side, the development of the import value of Indonesian spices from 1989-2017 also fluctuated and tended to increase from year to year. In 2011, the import value of Indonesian spices was very high due to the increase in domestic demand for commodities.

Indonesia's import growth rate is greater than the growth rate of its exports. During the period 2013-2017, Indonesia's import growth rate reached $30 \%$ per year, while the export growth rate was only $8 \%$ per year. From this growth rate, it can also be seen that the rate of added value of imports is greater than exports, so that Indonesia needs to be careful to maintain the export performance of its spices commodity. In order to reduce imports, Indonesia needs to pay attention to the spice processed product industry because domestic demand is more interested in these products because of their practical use and easy storage, besides making Indonesian spices have added value.

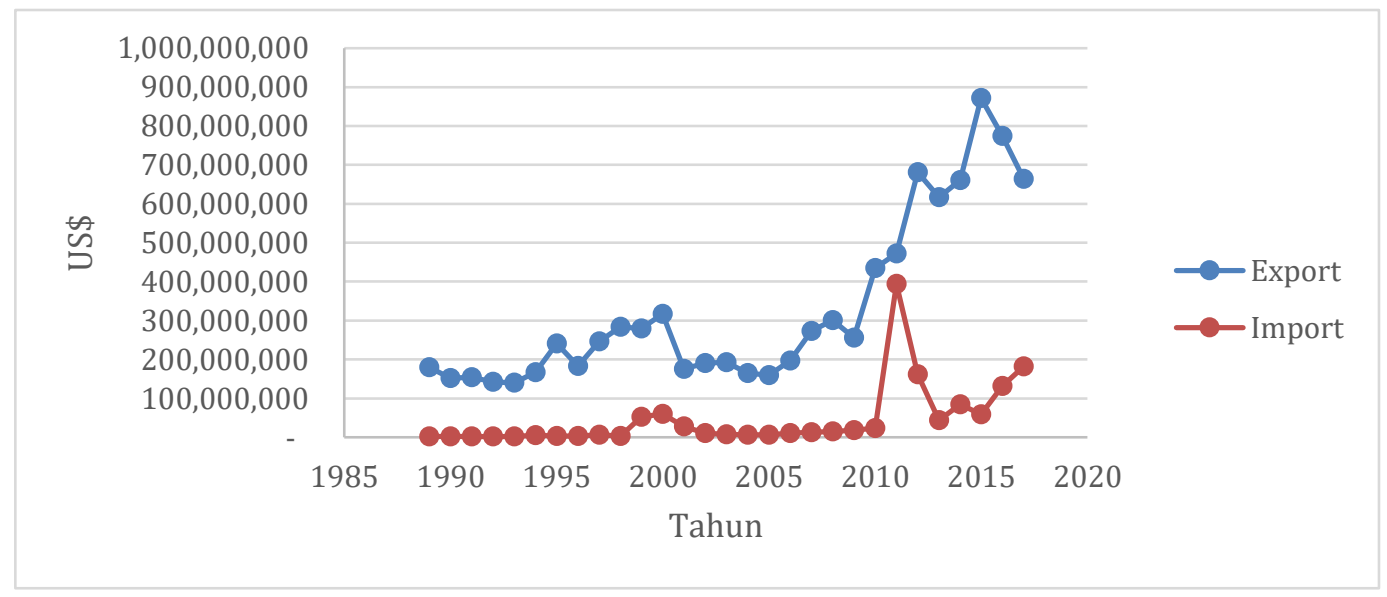


Figure 4. Graph of the Development of Export-Import Value of Indonesian Spice Commodities 1989-2017 Source: Secondary data analysis (UNCOMTRADE, 2019)

\subsection{Indonesian Spice Commodity Trade Performance}

The international trade balance for Indonesian spice commodities from 1989 to 2017 fluctuated, but was still in a surplus condition because the amount of exports was greater than the number of imports. In 2015, Indonesia's spice commodities experienced the highest trade surplus, amounting to US \$ 813 million. However, in 2016 and 2017 the value of Indonesia's trade balance decreased. In 2017, the trade balance value for Indonesian spices was US \$ 482 million. If you look at the growth of Indonesia's trade balance in each period it fluctuates but tends to increase. In the 2012-2017 period, there was a significant increase in the surplus of spices commodities with an average rate of added surplus value of $94.12 \%$ per year. The high increase in surplus during that period was due to a high increase in imports, but then in 2012 there was a decrease in import value reaching 58.92\% and on the other hand there was an increase in export value.

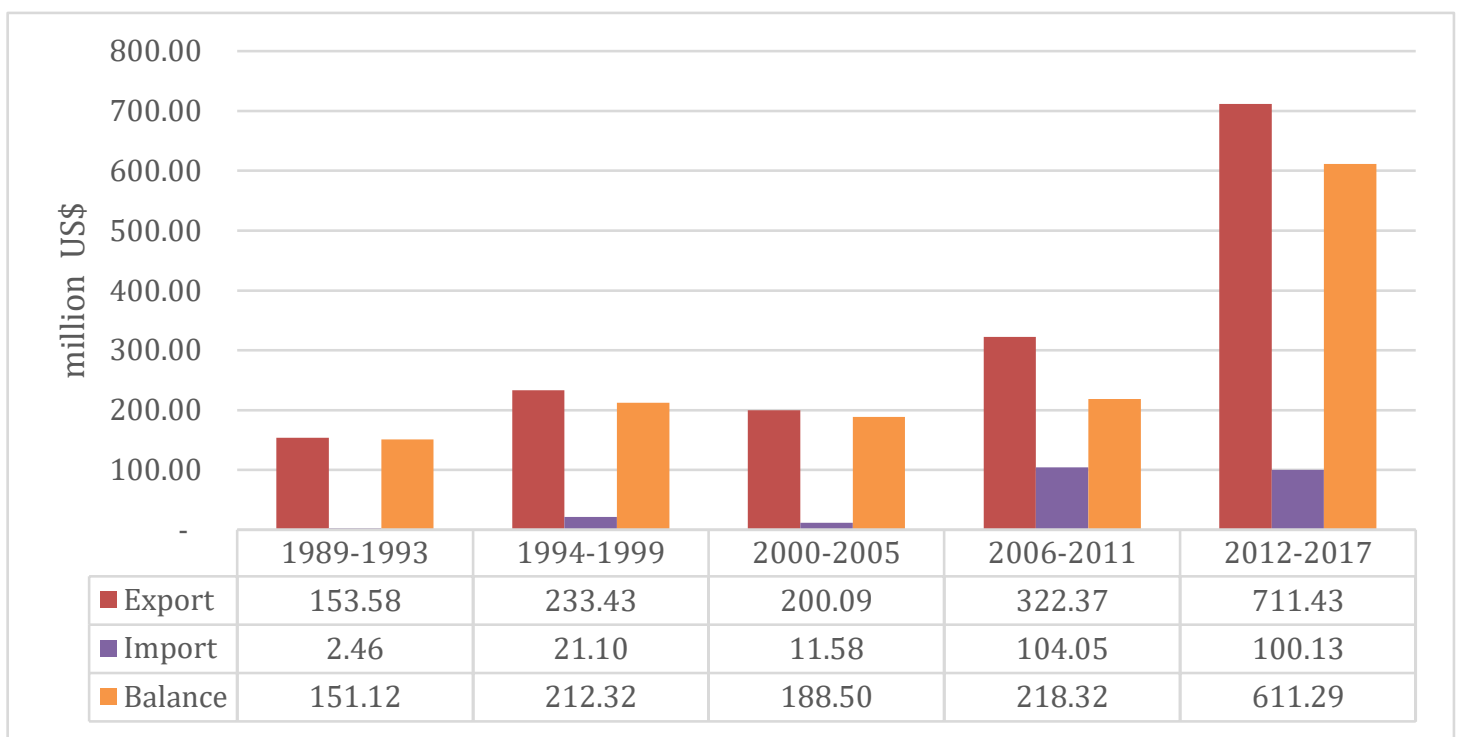

Figure 5. The Growth Histogram of the International Trade Balance for Indonesian Spice Commodities 19892017

Source: Secondary data analysis (UNCOMTRADE, 2019)

Based on Figure 5, it can be seen that the trade balance of spice commodities in Indonesia is fluctuating. Of course, this is caused by various factors, one of which is the increase and decrease in the price of these commodities over a certain period of time. The decline in the price of Indonesia's mainstay commodity will certainly affect Indonesia's trade balance. Such conditions in the future should be anticipated by Indonesia, especially considering the uncertain global economy so that challenges and improvements in maintaining Indonesia's trade balance must be optimized.

\subsection{Demand for World and Indonesian Spices in the International Market}

Every year, the demand for spices in the international market fluctuates but tends to increase. In 2017, the highest demand for spices was in the commodity group of pepper, chili and capsicum with a demand value of 3.98 billion US \$. Then followed by the biopharmaceutical commodity group with a demand value of 2.68 billion US \$. Followed by vanilla US \$ 1.36 billion, cinnamon 712 million US \$, cloves US \$ 611 million, and nutmeg, starch and cardamom US $\$ 479$ million. Judging from the rate of increase in demand for spices for 29 years (1989-2017) shows a positive trend with an average rate of increase in demand for spices of $12 \%$ per year. In the international market, the highest demand growth rate is vanilla. In 1989 the demand for vanilla was US $\$ 25$ million, increasing by $5,292 \%$ overall for 29 years with an average demand growth rate of $24.55 \%$ per year. Meanwhile, pepper, chili, and capsium had the lowest rate of increase in demand among other spice commodities with an average of $11.78 \%$ per year. In figure 6 , you can see the demand for spices in Indonesia 


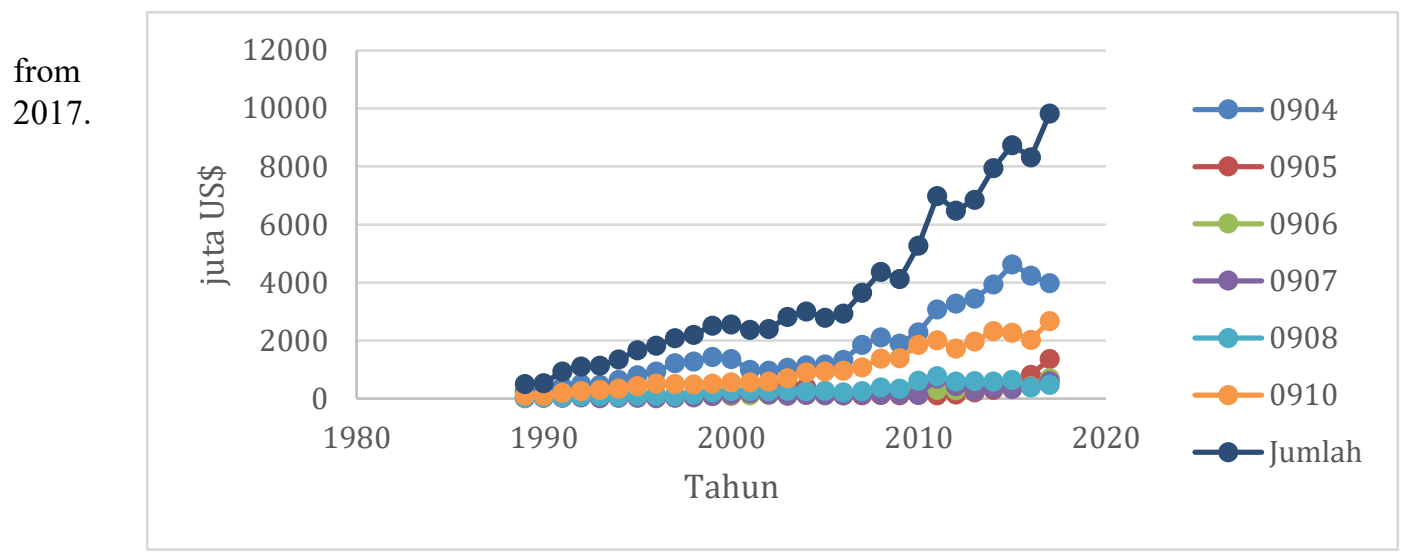

Information: HS0904 (Pepper, chilies, and capsium), HS0905 (Vanilla), HS0906 (Cinnamon), HS0907 (Clove), HS0908 (Nutmeg, anise, and cardamom), HS0910 (Ginger, turmeric, saffron, thyme, curry leaves , and bay leaves)

Figure 6.Graph of World Spices Demand 1989-2017

Source: Secondary data analysis (UNCOMTRADE, 2019)

The development of demand for Indonesian spices in the international market is dominated by commodity groups of pepper, chili and capsicum. This is in line with the increase in world demand for spices which is also dominated by these commodities. This is because the population is increasing so that consumption per capita is also increasing. In addition to this influence, there is also the influence of the price of these commodities which makes demand increase. Weather and climate also affect the planting of these commodities so that countries that are able to produce these commodities are the ones that meet the demand for these commodities. The next types of spices that dominate are nutmeg, anise, and cardamom. The growth rate of nutmeg is $123.16 \%$ with an average annual growth rate of $11.19 \%$. Among all types of spices that had the highest growth rate were cloves with a value of $5,237.20 \%$. This can be seen from the value of the demand for Indonesian cloves in the international market in 1989, namely 542 thousand US \$ then increased to 14 million US \$ in 2017. Even so, the demand for cloves is the lowest among other Indonesian spice commodities but the rate of increase in demand for cloves is average. - The highest average is $260.36 \%$ per year. Apart from cloves, the growth rate of other spice commodities is also on an upward trend. The vanilla growth rate is $551.79 \%$ with an average annual growth rate of $18.80 \%$; cinnamon $339.38 \%$ with an average annual growth rate of $8.27 \%$; nutmeg, lawang and cardamom $745.48 \%$ with an average annual growth rate of $11.90 \%$; and ginger $297.76 \%$ with an average annual growth rate of $15.71 \%$.

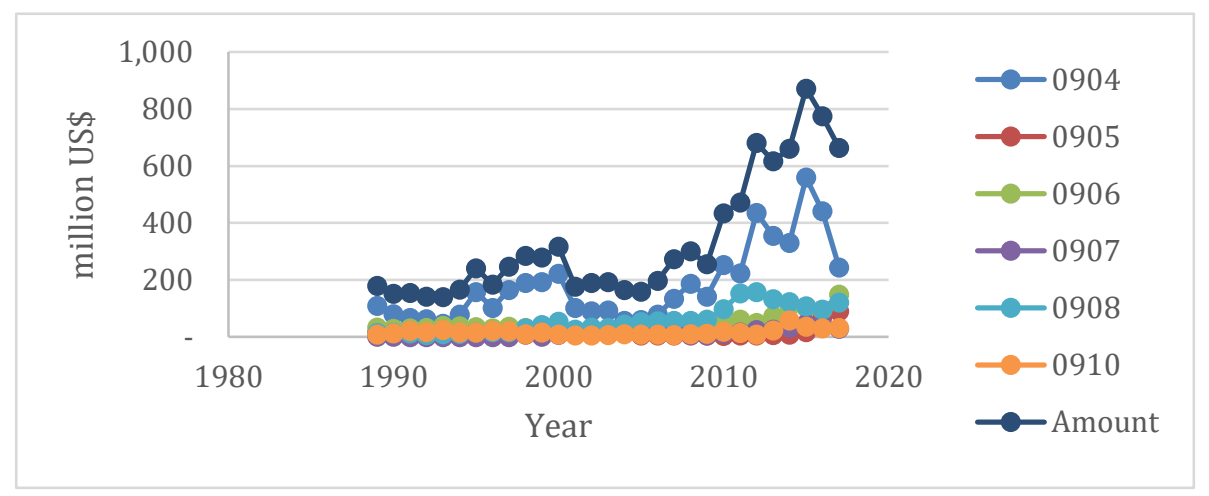

Information:

HS0904 (Pepper, chilies, and capsium), HS0905 (Vanilla), HS0906 (Cinnamon), HS0907 (Clove), HS0908 (Nutmeg, anise, and cardamom), HS0910 (Ginger, turmeric, saffron, thyme, curry leaves, and bay leaves)

Figure 7. Graph of Demand for Indonesian Spices in the International Market 1989-2017

Source: Secondary data analysis (UNCOMTRADE, 2019)

The demand for Indonesian spices can still increase by looking at opportunities in the international market. Indonesia needs to increase the quantity and quality of spice commodities in order to attract consumer interest 
and increase added value. Comparing the demand for world and Indonesian spices, there is good trade potential for Indonesia to expand its export share. Of course, this must be followed by several strategic steps that can be taken, such as increasing competitiveness and promoting the export of priority commodities of spices. This is supported by geographical support where the place is identical to the production of special spice commodities for the region so that it has good quality and characteristics because there is support from nature and traditional practices from generation to generation. Several countries have also taken this step as a means of branding with the ultimate goal of farmers' welfare. Indonesia currently has geographical indications that register 52 commodities including Muntok pepper, Minahasa cloves, Siau nutmeg, Lampung black pepper and others. With this, farmers also get protection from these promotional claims so that there is added value accompanied by increased marketing prices.

\subsection{Development of the Price of Spices}

Indonesian spices are traded in the form of raw products or in the form of preparations, oils, extract oils and natural dyes. Spices are used as ingredients in food, cosmetics, bathroom equipment, aromatherapy, pharmaceutical chemicals and perfumes. For food, usually the product will be mixed with flavors, be it sweet, sour, or bitter, spicy or vice versa and the usual meat or fish, soup and sauce ingredients and so on. Spices products are also consumed by a country to be resold as further processed commodities through domestic and international trade. This condition also causes differences in the character of the trade in natural and processed spices, as well as the various problems that follow (Indonesia Trade Promotion Center, 2013).

The development of international and domestic spice commodity prices in each period fluctuated for 29 years (1989-2017) (table 1). Indonesian pepper has a price above the world average with an increase in the price of pepper of $7.68 \%$ per year, while the rate of increase in world pepper prices is $3.16 \%$ per year. The commodities of pepper that are traded are mostly in the form of black and white pepper grains and in small amounts in the form of ground pepper, green pepper and pepper oil. New Indonesian Pepper takes advantage of the market for white pepper, black pepper and ground pepper. The prices of other Indonesian spices besides pepper have fluctuating prices, which are sometimes higher or lower than world prices.

Table 1. Development of Domestic and World Price of Spice Commodities 1989-2017

\begin{tabular}{lllllll}
\hline Comodity & Information & $1989-1993$ & $1994-1999$ & $2000-2005$ & $2006-2011$ & $2012-2017$ \\
\hline \multirow{2}{*}{ Pepper } & World & 1,63 & 2,55 & 1,78 & 2,66 & 4,17 \\
& Indonesia & 1,62 & 3,75 & 1,97 & 3,59 & 7,67 \\
\multirow{2}{*}{ Vanilla } & World & 39,28 & 25,87 & 52,42 & 17,31 & 83,52 \\
& Indonesia & 27,54 & 22,22 & 19,22 & 13,08 & 93,40 \\
\multirow{2}{*}{ Cinnamons } & World & 2,13 & 1,53 & 1,21 & 1,96 & 3,30 \\
& Indonesia & 1,86 & 1,44 & 0,55 & 0,89 & 1,87 \\
Clove & World & 1,51 & 1,02 & 3,14 & 4,10 & 7,73 \\
& Indonesia & 0,59 & 0,52 & 1,92 & 2,07 & 3,80 \\
\multirow{2}{*}{ Nutmeg } & World & 2,64 & 3,01 & 4,16 & 7,03 & 7,72 \\
\multirow{2}{*}{ Biofarmaka } & Indonesia & 1,80 & 2,41 & 2,87 & 4,06 & 5,57 \\
& World & 1,07 & 1,30 & 1,31 & 1,63 & 1,94 \\
& Indonesia & 0,45 & 0,47 & 0,34 & 0,26 & 0,36 \\
\hline
\end{tabular}

Source: Secondary data analysis (UNCOMTRADE, 2019)

Information: HS0904 (Pepper, chilies, and capsium), HS0905 (Vanilla), HS0906 (Cinnamon), HS0907 (Clove), HS0908 (Nutmeg, anise, and cardamom), HS0910 (Ginger, turmeric, saffron, thyme, curry leaves , and bay leaves)

The highest price development is vanilla, with a price that tends to increase every year, making trade in this commodity have bright prospects. This can encourage vanilla producers to increase their export volume. The growth rate of world vanilla prices is $806.74 \%$ and the growth rate of Indonesian vanilla prices is $1,501.49 \%$. In 1989 the world and Indonesian vanilla prices were US \$25.98/ $\mathrm{kg}$ and US \$ $19.52 / \mathrm{kg}$ then increased to US $\$ 235.60 / \mathrm{kg}$ and US $\$ 312.77 / \mathrm{kg}$ in 2017 . The high price of vanilla in comparison with other spice commodities because the process of planting and harvesting is not easy. 
In contrast to the price of vanilla, during the last 6 years (2012-2017), pepper, cloves, and nutmeg had a declining price growth rate, both world prices and Indonesian prices. Indonesian cloves, cinnamon, nutmeg, vanilla and biopharmaca are still below the world average. Indonesia needs to add value to the spice commodity in order to have a high export value. In addition, Indonesia also needs to improve the quality of spices. The opportunity to increase the export value of spice products, such as pepper, nutmeg and cinnamon, is still open and quite high. However, there needs to be an increase in quality, especially the handling of products during post-harvest and also productivity on the land so that the development of the downstream spice industry needs more attention. In Indonesia, most of the spices are used and traded at home and abroad (exported) in fresh form. In addition to reducing the added value of the spice commodity, it also reduces the quality and quality of the spice commodity because it is susceptible to contamination both from the origin of its growth and during distribution and storage. Some spices contain very high numbers of bacteria. The existence of deficiencies in post-harvest handling can hamper Indonesia's role in the trade of spice commodities on the international market. Therefore, farmers need to pay attention to post-harvest handling.

\section{Discussion}

Exchange activities or what is often referred to as international trade is an activity of exchanging goods on a voluntary basis. The purpose of this means that there is no coercion between the two parties in doing this. International trade occurs when both parties experience benefits and no one loses. The exchanges that occur between countries and nations are manifested in export and import activities. In fact, trade that occurs in International does not only include exports and imports but also services used such as travel, shipping, insurance, banking, communications and other things. Apart from the things already mentioned, it also includes capital such as the payment of profits, dividends and assistance between the two countries. The emergence of international relations activities that occur shows that the production of a country that is exported to another country is to meet the needs and vice versa, goods that are consumed or invested in the country are produced abroad and are sufficiently imported. Prices that occur in the international market will certainly affect domestic prices. For example, the price of raw materials, commodities or raw materials as input to the production process is of course influenced by world demand and supply. So that these price changes will greatly affect domestic prices. The manufacturing price will also influence this. The fall in the prices of foreign production relative to domestically produced goods leads to goods made in foreign countries. International relations that occur in the financial sector have an effect on the capital market or stock market at home and abroad. This action has a fundamental effect on the determination of income, exchange rate and the ability of modern policies that affect interest rates.

One of the countries that has become an international level economic actor is Indonesia. Evidence of this is indicated by Indonesia's activeness in exporting and importing. Many countries cooperate with Indonesia from trade to other aspects. The products in Indonesia cannot be denied that they are of quite good quality and are able to compete with other products from competing countries. Examples of products that are often exported are commodity spices such as ginger, pepper, vanilla and others. The Directorate General of Horticulture recorded data that there were approximately 26 destination countries that received ginger shipments from Indonesia. Some countries include Japan, Hong Kong, India to Bangladesh and other countries. It is recorded that approximately 500 tons of ginger exported to Bangladesh in the quarter of this year reached 500 tons. Basically, Indonesia has ginger products whose quality is able to compete, especially with ginger produced by Vietnam and Thailand when assessed from the content of essential oils, starches and fiber. This makes ginger from Indonesia more sought after by several countries that want to import this commodity. The economic value contained in ginger products is very high because the ginger commodity has many benefits and functions.

Besides ginger, there is vanilla commodity which is often considered green gold because it contains a fairly good selling price. In 2018 vanilla beans reached a selling price equivalent to US $\$ 650$ per kilogram (kg) but by mid-2020 the figure had decreased to US $\$ 200$ per $\mathrm{kg}$. If you look at the export trend of Indonesian vanilla products, Indonesia has a positive trend with a growth of around $32.55 \%$ in the 2015 to 2019 period. In fact, Indonesia has made an achievement in being the third highest exporter of vanilla commodity in 2019 under Madagascar and France. This vanilla is exported to several countries, such as the United States, which receives Indonesian vanilla production of 5000 kilograms.

Indonesia is blessed with abundant natural resources, including spices that are useful for adding flavor and 
aroma to dishes. Apart from pepper, the commodity that was the target of Europeans was nutmeg. As a result of the history of spice exploration in the past, Indonesia has developed into a global trade destination. Almost all countries in Europe such as Germany and Italy import nutmeg from Indonesia. You can find nutmeg in almost all European kitchens. The European Union hopes that Indonesia will continue to produce the best quality nutmeg. This is because the demand for this type of spices in the future will never subside. Indonesia is the world's largest producer of nutmeg and the largest exporter for the European market. So naturally in the future, there is no reason for Europe to reduce the demand for nutmeg from Indonesia.

The export growth of pepper in the first quarter of 2020 decreased by $0.36 \%$. In the 2019 period, the five largest pepper exporting countries in the world were recorded, namely Vietnam with USD 502.66 million (37.50 percent market share), Brazil USD 178.62 million (13.33 percent), Indonesia USD 116.08 million (8.66 percent), India with USD 79.89 million (5.96 percent), and Germany with USD 65.68 million (4.90 percent). The five export destination countries for Indonesian pepper in 2019, namely Vietnam amounted to USD 46.57 million (31.61 percent market share), China USD 21.06 million (14.29 percent), India USD 18.76 million (12.73 percent), the United States USD 16.45 million (11.17 percent), and Germany with USD 8.66 million (5.88 percent).

To increase the export of pepper in domestic and international markets, the government have done diversify its products and develop export markets. Product diversification aims to enable us to export value-added processed pepper, not only in raw form. Thus, the added value of pepper processing will be enjoyed by Indonesia, not other countries. Diversification and adaptation strategies for pepper products need to be continuously developed as an effort to increase the value of export competitiveness, including the development of global local brands, as well as fast handling of product certification such as halal, organic, good manufacturing practices, sanitary and phytosanitary ( sanitary and phytosanitary), including certification.

Apart from the commodity of pepper, ginger and vanilla, Indonesia also supplies the world market in the form of cinnamon, which reaches $85 \%$. Exporters carried out by Indonesia are also followed by good cinnamon producers because several places have good areas for planting cinnamon. Indonesia is known for its plant commodities in the form of spices. Cloves and nutmeg are Indonesia's superior seeds, but don't forget cinnamon, which is also a leading spice commodity in the export market. Indonesian exports in the form of cinnamon are formed in several types such as rolls and powder. This commodity is basically still very much in demand by several countries in the international market, especially countries from the European continent, which have been registering demand for cinnamon from Indonesia for several years. The volume of cinnamon exports has increased from 2011 to 2013. It is recorded that in 2011 the export volume reached 45,695 followed by a slight decrease in 2012 of 40,403 tons and increased again in 2013 amounting to 52,507 tons.

The conclusion showed that in general the acreage and production of spices commodities tended to increase from year to year, This was also followed by an increase in demand and an increase in exports of Indonesia's mainstay commodity, namely spices. When viewed from the balance of the Indonesian spices trade in each period it fluctuates but tends to increase. Meanwhile, the demand for spices in the international and Indonesian markets fluctuates every year but tends to increase and the development of international and domestic spice commodity prices has fluctuated each period.

${ }^{1}$ Hakim, L. (2015). Rempah \& Herba (Issue 164). Indonesia: Diandra Pustaka Indonesia.

2 Yuliati, L. (2012). Intra-Industry Trade sebagai alternatif dalam mengatasi dampak krisis global di Indonesia. Trikonomika, 11(1), 96-110.

${ }^{3}$ Hermawan, Iwan. (2015). DAYA SAING REMPAH INDONESIA DI PASAR ASEAN PERIODE PRA DAN PAScA KRISIS EKONOMI GLOBAL. Buletin Ilmiah Litbang Perdagangan, 153-178.

${ }^{4}$ FAO. (2014). New quality criteria to be developed for booming spice and herb sector.

${ }^{5}$ Sutriyanto, E. (2014). Dalam 5 Tahun Restoran Kelas Menengah Tumbuh 250 persen. Retrieved April 4, 2021 , from Tribunbisnis website: http://www.tribunnews.com/bisnis/2014/04/02/dalam-5-tahun-jumlahrestoran-kelas-menengah-tumbuh-250-persen 
${ }^{6}$ Lakner, Zoltán, Erzsébet Szabó, Viktória Szücs, and A. S. (2018). Network and Vulnerability Analysis of International Spice Trade. Food Control, 83, 141-146.

${ }^{7}$ Ferry, Y. (2013). Prospek pengembanga kayu manis (Cinnamomun Burmanii L) di Indonesia. SIRINOV, 1(1), $11-20$.

${ }^{8}$ Manurung, H. (2021). Enhancing Bilateral Cooperation: Indonesia-Russia Defense Relations. Journal of Advance in Social Sciences and Policy, 1(1), 27-42. https://doi.org/10.23960/jassp.v1i1.28

${ }^{9}$ Kis-Katos, K., \& Sparrow, R. (2015). Poverty, labor markets and trade liberalization in Indonesia. Journal of Development Economics, 117, 94-106.

${ }^{10}$ Benesova, I., Maitah, M., Smutka, L., Tomsik, K., \& Ishchukova, N. (2017). Perspectives of the Russian Agricultural Exports in terms of Comparative Advantage. Agricultural Economics (Czech Republic). AGRICECON, 63(7), 318-330.

${ }^{11}$ Beaudreau, B. C. (2011). Vertical comparative advantage. International Trade Journal, 25(3), 305-348.

12 Laursen, K. (2015). Revealed comparative advantage and the alternatives as measures of international specialization. Eurasian Business Review, 5(1), 99-115.

${ }^{13}$ Chasanah, N., Mulyo, J. H., \& Darwanto, D. H. (2017). Competitiveness and Export Similarity of Indonesian Horticulture in The Asean-Asean+3. Agro Ekonomi, 28(1), 32. https://doi.org/10.22146/jae.25583

${ }^{14}$ Rosman, R. (2005). Status dan Strategi Pengembangan Panili di Indonesia. Perspektif, 4(2), 43-54.

15 DHALIMI, A. (2020). PENGARUH DOSIS DAN CARA PELETAKAN PUPUK TERHADAP PERTUMBUHAN TANAMAN KAYUMANIS (Cinnamomum burmanii ROBX). Jurnal Penelitian Tanaman Industri, 12(3), 98. https://doi.org/10.21082/jlittri.v12n3.2006.98-102

\section{References}

Beaudreau, B. C. (2011). Vertical comparative advantage. International Trade Journal, 25(3), 305-348.

Benesova, I., Maitah, M., Smutka, L., Tomsik, K., \& Ishchukova, N. (2017). Perspectives of the Russian Agricultural Exports in terms of Comparative Advantage. Agricultural Economics (Czech Republic). AGRICECON, 63(7), 318-330.

Chasanah, N., Mulyo, J. H., \& Darwanto, D. H. (2017). Competitiveness and Export Similarity of Indonesian Horticulture in The Asean-Asean+3. Agro Ekonomi, 28(1), 32. https://doi.org/10.22146/jae.25583

DHALIMI, A. (2020). PENGARUH DOSIS DAN CARA PELETAKAN PUPUK TERHADAP PERTUMBUHAN TANAMAN KAYUMANIS (Cinnamomum burmanii ROBX). Jurnal Penelitian Tanaman Industri, 12(3), 98. https://doi.org/10.21082/jlittri.v12n3.2006.98-102

FAO. (2014). New quality criteria to be developed for booming spice and herb sector.

Ferry, Y. (2013). Prospek pengembanga kayu manis (Cinnamomun Burmanii L) di Indonesia. SIRINOV, 1(1), $11-20$.

Hakim, L. (2015). Rempah \& Herba (Issue 164). Indonesia: Diandra Pustaka Indonesia.

Iwan Hermawan. (2015). DAYA SAING REMPAH INDONESIA DI PASAR ASEAN PERIODE PRA DAN PAScA KRISIS EKONOMI GLOBAL. Buletin Ilmiah Litbang Perdagangan, 153-178.

Kis-Katos, K., \& Sparrow, R. (2015). Poverty, labor markets and trade liberalization in Indonesia. Journal of Development Economics, 117, 94-106.

Lakner, Zoltán, Erzsébet Szabó, Viktória Szücs, and A. S. (2018). Network and Vulnerability Analysis of International Spice Trade. Food Control, 83, 141-146.

Laursen, K. (2015). Revealed comparative advantage and the alternatives as measures of international specialization. Eurasian Business Review, 5(1), 99-115.

Manurung, H. (2021). Enhancing Bilateral Cooperation: Indonesia-Russia Defense Relations. Journal of Advance in Social Sciences and Policy, 1(1), 27-42. https://doi.org/10.23960/jassp.v1i1.28

Niviati, L. N. \&. (2015). Outlook Lada (Komoditas Pertanian subsektor Perkebunan).

Perkebunan, D. J. (2013). Peningkatan produksi, produktivitas dan mutu tanaman rempah dan penyegar. Jakarta. 
Rosman, R. (2005). Status dan Strategi Pengembangan Panili di Indonesia. Perspektif, 4(2), 43-54.

Sutriyanto, E. (2014). Dalam 5 Tahun Restoran Kelas Menengah Tumbuh 250 persen. Retrieved April 4, 2021, from Tribunbisnis website: http://www.tribunnews.com/bisnis/2014/04/02/dalam-5-tahun-jumlahrestoran-kelas-menengah-tumbuh-250-persen

Yuliati, L. (2012). Intra-Industry Trade sebagai alternatif dalam mengatasi dampak krisis global di Indonesia. Trikonomika, 11(1), 96-110. 